\title{
Global Dispersion of Current Accounts: Is the Universe Expanding? \\ PRELIMINARY
}

\author{
Hamid Faruqee and Jaewoo Lee ${ }^{1}$
}

\section{Introduction}

Few external variables are as closely or widely watched as the current account balance.

Rightly or wrongly, it has been used as a barometer for a wide range of economic conditions - from the state of the business cycle to the sustainability of external financing. In recent years, attention to current account imbalances has taken on a global dimension, reflecting concern over "global imbalances." At the center is a large (albeit moderating) current account deficit in the United States, reflecting a shortfall of domestic saving relative to investment on the order of five to six percent of GDP. As a counterpart, large and/or growing current account surpluses have been recorded in Japan, [Canada,] China and other emerging Asia, but less so in Europe (excluding Russia). Whether such a global constellation of widening external imbalances can be sustained and for how long constitutes a key macroeconomic risk facing the world economy. ${ }^{2}$ Namely, the possibility of a hard landing in

\footnotetext{
${ }^{1}$ IMF. Email: hfaruqee@imf.org and jlee3@imf.org. We appreciate comments by Menzie Chinn, Pierre-Olivier Gourinchas, and participants in the 2006 AEA meeting. Of course, we are solely responsible for errors and misinterpretations. This paper should not be reported as representing the views of the IMF. The views expressed in this presentation are those of the author and should not be attributed to the International Monetary Fund, its Executive Board, or its management.
}

2 See IMF WEO (2005), Blanchard et. al (2005), Chinn and Lee (2005), Faruqee et al. (2006a,b), and Gourinchas and Rey (2005). 
the U.S. dollar - the international currency of choice - has raised concerns in many parts of the world over the potential fallout from a disorderly global rebalancing.

A notable countervailing argument to such concerns was perhaps most notably voiced by former Fed Chairman Alan Greenspan. Turning matters around, he has argued that the unprecedented size of the U.S. deficit was itself a testimony to the increasingly efficient functioning of international capital markets and its ability to mobilize such a large share of net saving from the rest of the world to the United States. Specifically, he noted the following stylized fact regarding global trade and capital flows:

Uptrends in the ratios of external liabilities or assets to trade, and therefore to GDP, can be shown to have been associated with a widening dispersion in countries' ratios of trade and current account balances to GDP. A measure of that dispersion, the sum of the absolute values of the current account balances ...has been rising as a ratio to GDP at an average annual rate of about 2 percent since 1970 for the OECD countries, which constitute fourfifths of world GDP...

More generally, the vast savings transfer has occurred without measurable disruption to the balance of international finance...Accordingly, the trend... will likely continue as globalization proceeds. [Remarks at $21^{\text {st }}$ annual monetary conference at Cato Institute, November 2003]

This paper reexamines the global distribution of current accounts viewed from a longer term perspective. Using a panel of over one hundred countries that comprise over 95 percent of world output, the analysis establishes a set of "stylized facts" regarding the individual and collective behavior of current accounts over the past four decades. In particular, we examine the dispersion properties of external imbalances and interpret these empirical regularities in the context of increasing openness in trade and financial flows - often referred to as "globalization." While an emergent literature on financial globalization has documented that 
gross financial flows (including international reserve accumulation) has increased dramatically in recent years, what does this imply (if anything) for net flows? $?^{3}$ More specifically, the central issues that the paper addresses include the following:

- Is the universe of current accounts expanding or narrowing? And, at what rate? What component of the U.S. external deficit specifically (and global imbalances broadly) can be attributed to the underlying changes in global dispersion?

- What does changing global dispersion imply for current account persistence? What are the sources-trade or income?

- What economic factors help explain underlying trends in the dispersion of external imbalances?

Besides risk and policy implications, the question of rising dispersion has a direct bearing on the celebrated Feldstein-Horioka puzzle. Their basic finding that savings are closely correlated with investments across countries has remained more or less intact, despite several prominent exceptions (e.g., Blanchard and Giavazzi for Europe). Our query on rising dispersion would help to answer whether the background for the Feldstein-Horioka findings remains relevant. If there is no trend change in the dispersion of current accounts, FeldsteinHorioka correlations should continue to be confirmed in the data with statistical significance as strong as the original results. If instead a rising trend is identified in the dispersion of

\footnotetext{
${ }^{3}$ For recent studies on financial globalization see Prasad and other (2003), Kose and others (2006), and the references cited therein.
} 
current accounts, it would suggest that these findings would likely weaken over time, though not necessarily becoming extinct.

The paper is organized as follows. Section 2 examines whether the global constellation of current accounts has been narrowing or expanding over time, using several convergence measures. Section 3 examines current account stationarity and persistence and the implications of increasing dispersion. Section 4 examines the role of economic openness in expanding the universe of current account balances. Section 5 concludes. The appendix contains description of data, and two sections that are complementary to the paper's results.

\section{Dispersion \& Convergence}

We first ask if the global constellation of current account imbalances has been expanding or narrowing over time. Conceptually, in the case of convergence, there is a universally unique end point - i.e., zero balance - around which all current accounts should converge (up to a discrepancy term). But predictions from economic theory are generally ambiguous on this or whether external balances should gravitate toward an alternative or, even, a degenerate distribution. The answer typically depends on the class of model-e.g., representative agent versus overlapping generations framework - and its assumptions regarding market completeness, initial conditions, and the history of shocks. Hence, whether current accounts actually converge or diverge and over what horizon are essentially empirical questions. To examine these issues more closely, we employ both non-parametric and parametric methods - including concepts from the growth literature on convergence - to determine if the universe of current accounts is expanding. 


\section{$\underline{\text { Unconditional Distributions }}$}

The unconditional distribution of current account ratios (in percent of GDP) at different points in time are shown in Figure 1. Kernel density estimates of the cross-sectional distribution for 101 countries suggest that the universe of current accounts has been generally expanding. ${ }^{4}$ As shown in the figure, the distribution of current accounts shows a steady increase in dispersion from 1960 to 2004, with the mass of the distribution being less concentrated in the area around zero and moving further out toward the tails. ${ }^{5}$ The notable exception to this progressive pattern of expansion is the year 1980, when presumably the effects of oil shocks widened the dispersion of current accounts temporarily beyond that seen in later years. Notice too that the distributions for each year are not exactly centered around zero (but a small negative value), consistent with the global current account discrepancy. ${ }^{6}$

${ }^{4}$ The kernel estimator for an arbitrary point $x_{i}$ in the distribution is:

$$
f\left(x_{i}\right)=\frac{1}{N h} \sum_{j=1}^{N} K\left[\frac{x_{i}-X_{j}}{h}\right],
$$

where $X_{j}$ is the $j$ th data observation, $N$ is the number of observations, $h$ is the window size (i.e., the degree of smoothing), and $K$ is the kernel or weighting function. The nonparametric estimates in Figure 1 are based on the Epanechnikov kernel; See Silverman (1986). Results using the less efficient Gaussian kernel (i.e., standard normal) are very similar.

${ }^{5}$ Jarque-Bera tests strongly reject normality for each of these years. Skewness in the distribution was found significant for each of these years, except 1960; excess kurtosis (i.e., "fat tails") was statistically significant throughout.

${ }^{6}$ The global current account discrepancy-ususally expressed in dollar terms or in percent of world imports or GDP_- has tend to be negative since the early 1970s, reflecting 
Figure 1. Global Distribution of Current Accounts, 1960-2004

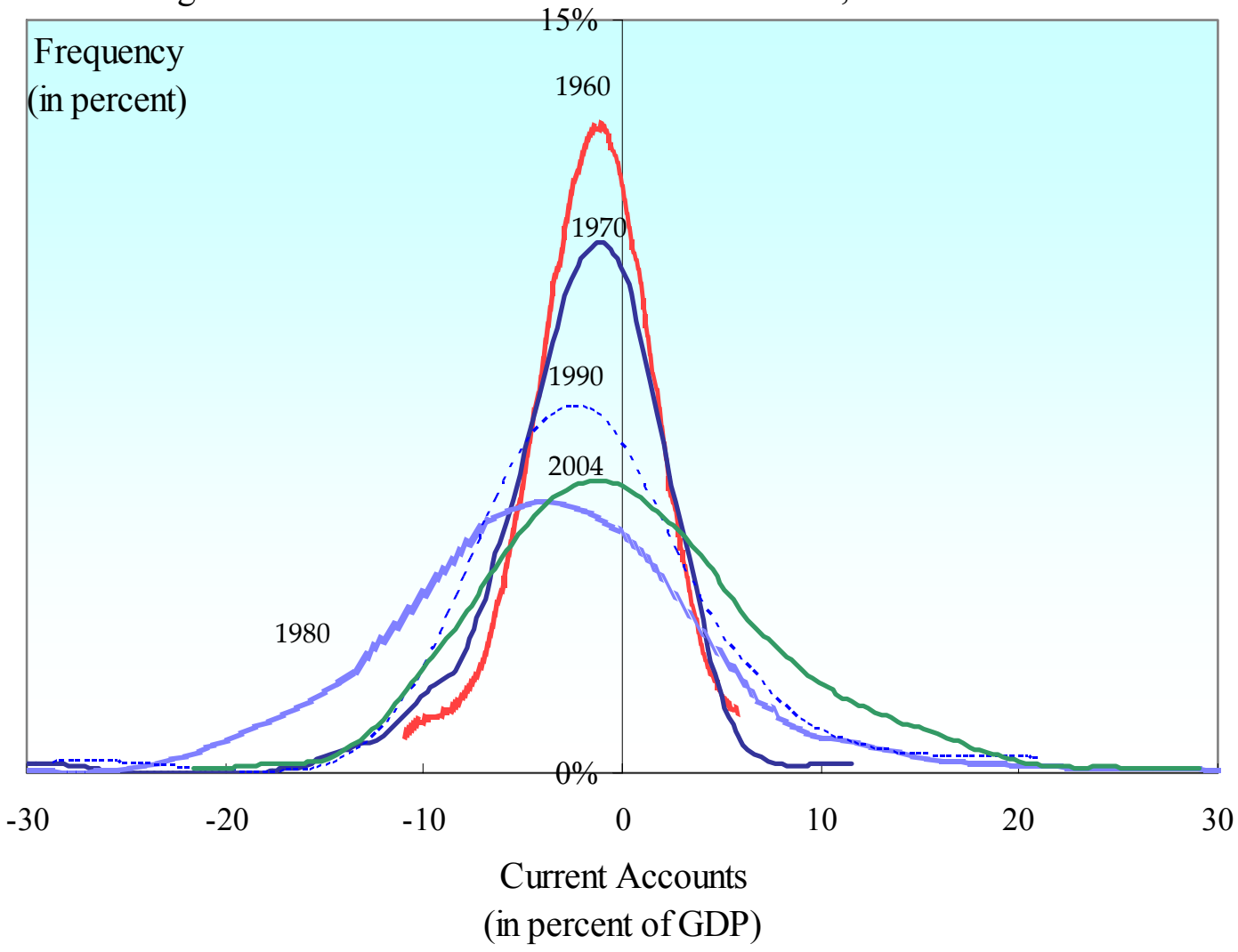

\section{$\underline{\sigma \text {-convergence }}$}

Figure 2 presents supporting evidence from a time-series perspective. The figure plots annually two standard dispersion measures of current account ratios over the past 45 years. They are the global standard deviation of current accounts (in percent of GDP) or $\sigma$, and the global mean absolute deviation of the current account (in percent of GDP) or $\mu$, both calculated across countries for each year.

discrepancies in both trade and income accounts; see Marquez and Workman (2001) for a discussion. 
Two features of the figure are worth noting. First, dispersion shows significant time variation from year to year. Consistent with the impression from the previous figure, notice the considerable increase in the global spread around the time of the two major oil shocks in the mid- and late-1970s. Second, an underlying trend increase in dispersion is apparent, consistent with the global distributions shown in Figure 1. Specifically, the universe of current account positions has been expanding on average by almost 2 percent per annum, measured by its standard deviation. ${ }^{7}$ This latter finding suggests a lack of so-called " $\sigma$ convergence" in external positions over this time horizon.

Note that both measures are unweighted, treating each country symmetrically. For comparison, a third measure of dispersion $\sum$ is shown in the figure by computing the global sum of current accounts (in absolute value) in percent of world GDP. This is equivalent to a weighted mean absolute deviation of current accounts (in dollar terms), where country weights are determined by own GDP (in dollar terms) as a share of world GDP (in dollar terms). All three measures are highly correlated (with correlation coefficients between $(0.60$ and 0.95 ). However, the third measure shows a steeper increase, particularly in recent years, well ahead of the other (unweighted) measures. ${ }^{8}$ This corresponds to emergence of "global

\footnotetext{
${ }^{7}$ A regression of the $(\log )$ standard deviation on a time trend yields the following results (with corrected standard errors given in parentheses):

$\ln \left(\sigma_{C A / G D P}\right)=1.4+0.017 t+\varepsilon_{t} ; R^{2}=0.33$

${ }^{8}$ Over the sample, the rate of increasing global dispersion is $1 \frac{1 / 2}{2}$ to $13 / 4$ perent per year on an unweighted basis and $3 \frac{1}{4}$ percent on a weighted basis.
} 
imbalances" where large deficits and surpluses emerged in the largest countries such as the United States and China.

Figure 2. Global Dispersion of Current Accounts, 1960-2004

(in percent of GDP)

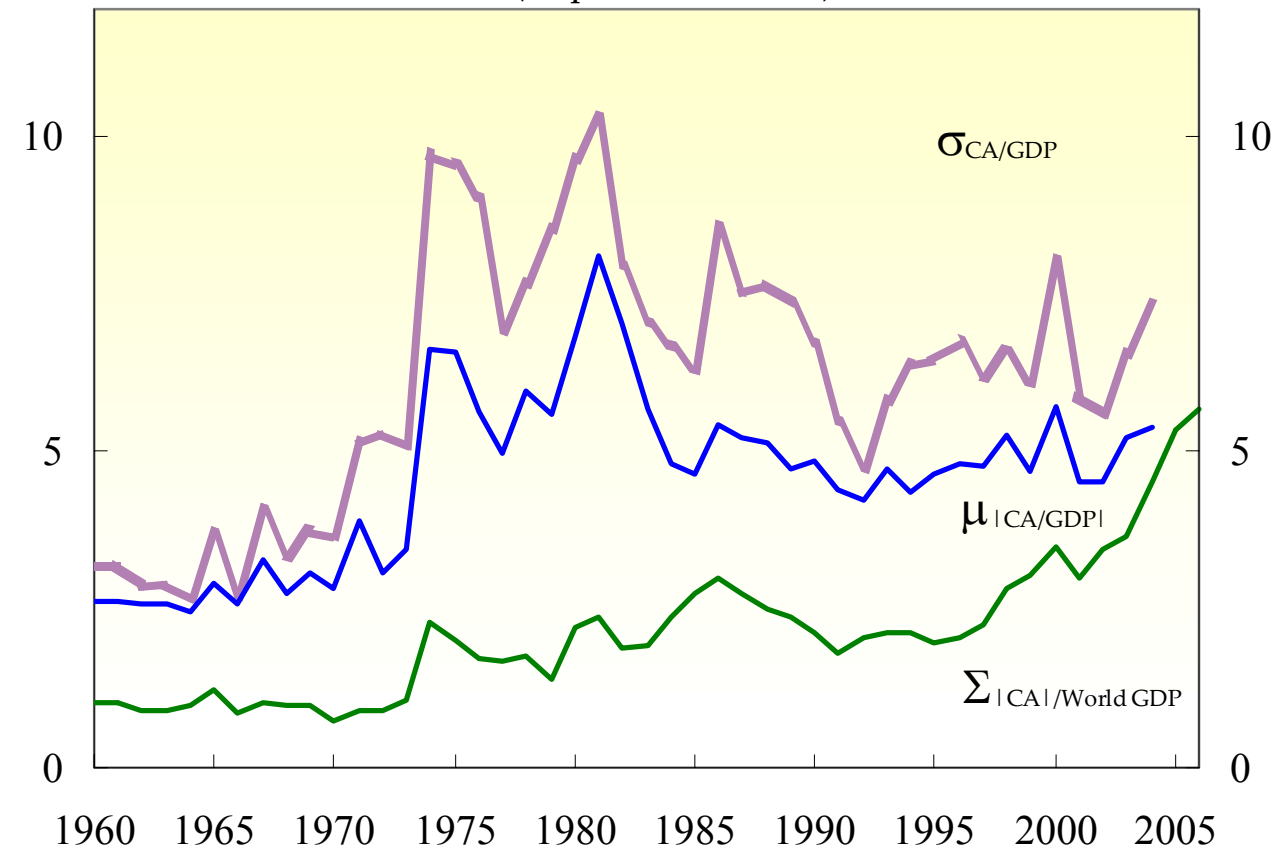

Notes: $\sigma$ denotes global standard deviation of current accounts (in percent of GDP); $\mu$ denotes global average of absolute values of current accounts (in percent of GDP); $\Sigma$ denotes global sum of absolute values of current accounts (in percent of world GDP);

\section{$\beta$-convergence}

Another convergence perspective - commonly used in the growth literature-is the notion of " $\beta$-convergence." In the context of current accounts, $\beta$-convergence would require that countries accumulating past imbalances eventually unwind these positions. This would allow current accounts (and trade balances) globally to converge to more similar values around 
zero-i.e., the convergence point. ${ }^{9}$ For example, countries with a large stock of net external debt, reflecting flow deficits in the past, would need to run current account surpluses in the future to pay down the debt or, at least, smaller current account deficits to decrease the share of debt relative to the overall economy. Comparing the initial net foreign asset ratio to the average current account ratio in subsequent years, however, provides very little support for this type of convergence. The cross-country regressions, in fact, show that countries with larger net indebtedness are more likely to run larger (not smaller) current account deficits in the years that follow. See figure $3 .^{10}$ And the results of the cross section regression are:

$$
C A_{\text {avg }}=-1.94+0.09 N F A_{0}+v ; R^{2}=0.13 ; \quad N O B S=94
$$

Moreover, the slope of the line drawn is greater than typical estimates of nominal growth in GDP, suggesting these subsequent flow imbalances tend to augment the net stock of external assets or liabilities in relation to the size of the economy. Alternative coefficient estimates may be more comparable to nominal dollar growth rates. This would imply a reversion to the

\footnotetext{
${ }^{9} \mathrm{~A}$ weaker form of convergence posits that current accounts, but not trade balances nor net foreign asset positions, converge toward balance. This would require that trade (not current account) surpluses be achieved in the years following current account deficits to stabilize the accumulation of net foreign liabilities. Net foreign assets data are based on Lane and MilesiFerretti (2001 and 2007).

${ }^{10}$ Chinn and Prasad (2002) find a similar effect of net foreign assets on current accounts based on multivariate panel estimation that controls for a wide range of explanatory variables (e.g., demographics, fiscal positions, economic development, etc).
} 
initial ratios of NFA to GDP, but this is still at variance with the notion of a convergence to a common value (e.g. zero balance). ${ }^{11}$

Figure 3. Net Foreign Assets v. Current Accounts

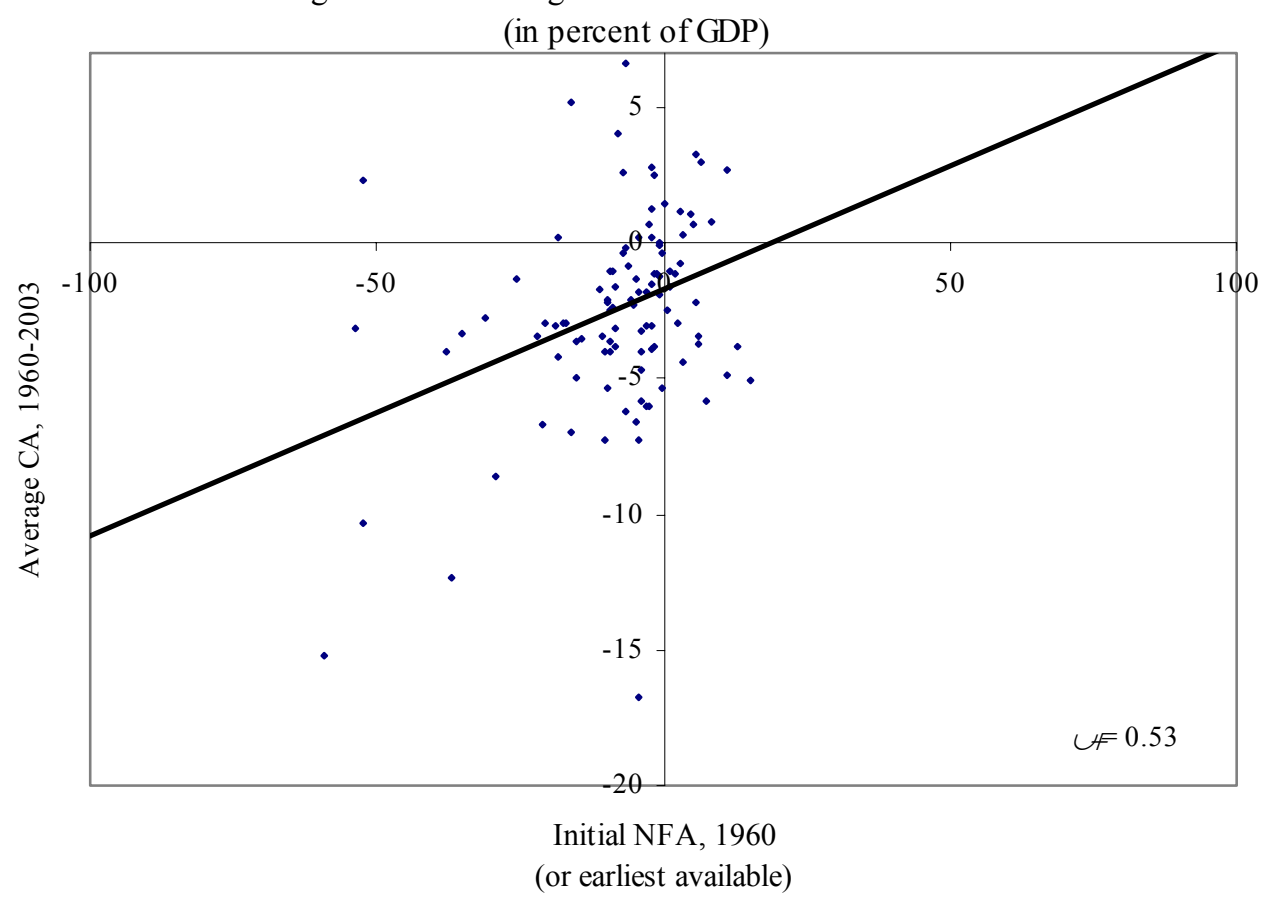

This result is comparable to the findings of Kraay and Ventura (2000). Using the data from less than 20 industrial countries, they found that current account imbalances are proportional to the net external balance sheet positions. In response to an increase in savings, a creditor country tended to run surplus while a debtor country tended to stay in deficit. They view this to be the result of a portfolio choice in the presence of a large investment risk. While data

${ }^{11}$ Dropping outlier countries with average current account imbalances (net external assets) greater than 10 percent (50 percent) of GDP in absolute terms would slightly lower the coefficient on initial NFA (to 0.06 ) but raise its significance level ( $p$-value $=3 \%$ ). 
limitation makes it difficult to examine the validity of their prediction for a wider set of countries, their model is one possible explanation for the result that we find for a very large set of countries.

To recap, the distributional and convergence properties of current account balances suggest an expanding universe. The $\beta$-convergence results further suggest that countries who have had current account imbalances historically are the group more likely to run subsequent current account imbalances (of the same sign) in ensuing periods, leading to further accumulation of net foreign assets or liabilities.

\section{Stationarity \& Persistence}

We now examine aspects of the time-series properties of current accounts-in particular, stationarity and persistence. Trehan and Walsh (1991) showed that the stationarity of the current account is a sufficient condition for the intertemporal budget constraint to hold. ${ }^{12}$ Stationarity has since been an indirect test of the basic premise of the intertemporal view of the current account. Thus, this type of behavior would indicate whether the expanding global dispersion of current accounts has also been compatible with respecting intertemporal budget constraints.

${ }^{12}$ Trehan and Walsh showed that the stationarity of the current account was the necessary and sufficient condition, but the necessity was debated lately by Bohn (2006). 
To examine the stationarity and persistence properties of current accounts, a battery of unit root and stationarity tests were conducted. In particular, the well-known augmented DickeyFuller (ADF) test and non-parametric Phillips-Perron (PP) test for a unit root against a stationary alternative were applied to the individual country series for the current account ratio (in percent of GDP). In addition, the Kwiatowski et al (1992) (KPSS) test for stationarity against a unit root was also used. The corresponding test statistics and significance levels are shown in the appendix. ${ }^{13}$

Figure 4 summarizes the rejection and non-rejection rates (in percent) for these unit root tests. For more straightforward comparisons, the rejection of stationarity under the KPSS test is reported as a non-rejection of the unit root. Overall, the picture is quite mixed. One test finds the majority of current accounts to be non-stationary (ADF test), another tests finds the majority to be stationary (KPSS test), and the third test is split down the middle (PP test).

Individually, for nearly a quarter of the sample (22 of 101), these tests failed to reject both non-stationarity and stationarity for the same series (see appendix). This finding highlights two widely-known features of these tests and the time-series data: (1) unit root and stationarity tests tend to have low power (i.e., fail to reject too often) in finite samples, and

\footnotetext{
${ }^{13}$ In all cases, the model specification includes a constant but no time trend. Including a time trend in the unit root tests marginally increase the number of rejections.
} 
(2) the current account is generally a very persistent series, making it difficult to distinguish between non-stationary and stationary alternatives over limited time spans. ${ }^{14}$

Figure 4. Unit Root Test Rejection Rates

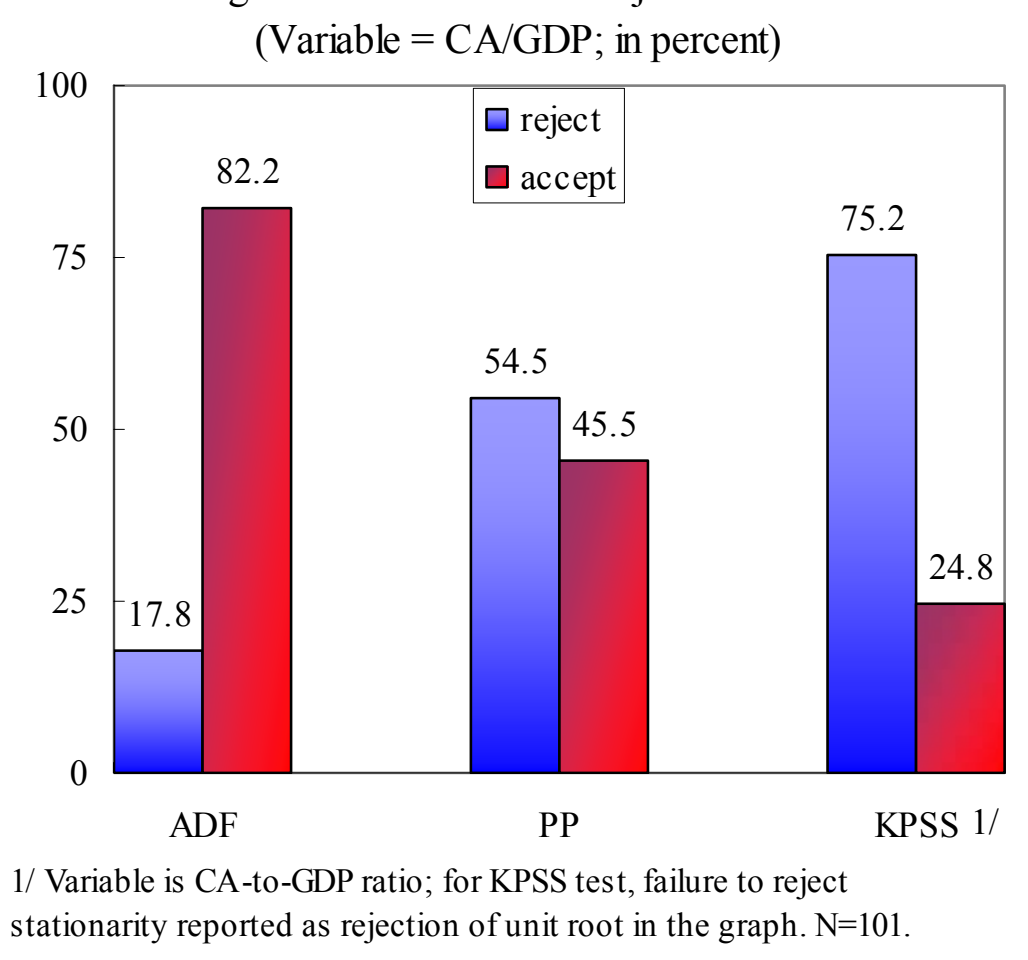

For 21 countries - including, notably, the United States and Japan, the tests indicated (at least, statistically) a non-stationary current account ratio over this time span. That is, the unit root tests failed to reject non-stationarity and the KPSS test further rejected stationarity. But for more than half of the sample ( 55 of 101 countries), at least one of the two unit root tests reject and the stationarity test accept their respective null hypotheses, suggesting a stationary series.

\footnotetext{
${ }^{14}$ See Campbell and Perron (1991). A peculiar finding is that for three countries, these lowpowered tests rejected both stationarity and non-stationarity for at least one unit root test.
} 
Moreover, on the basis of panel unit root tests (Table 1), non-stationarity is strongly rejected. The tests were applied to three panels comprising different groups of countries according to data availability. The first panel comprises data from 1960 to 1998 for 50 countries, the second panel comprises data from 1971 to 1998 for 82 countries, and the third panel comprises data from 1980 to 1998 for 94 countries (excluding Kuwait). The null of nonstationarity is strongly rejected for all possible specifications suggested by Levin and Lin (1992), Im, Pesaran and Shin (1995), and Breitung (2000); see appendix. Test statistics reported in the table correspond to specifications without time trend, but a unit root was rejected for specifications with time trend, too.

Overall, these various tests suggest that the current account is a stationary but persistent series. To further highlight this point, simple AR(1) specifications for the current account are reported in appendix (Table A2). The average autoregressive coefficient across country estimates is 0.58 . From a panel perspective, pooled OLS and fixed effects estimates, respectively, yield the following equations (with corrected standard errors in parentheses):

$$
\begin{gathered}
C A_{i t}=k+\underset{(0.02)}{0.75} C A_{i t-1}+\varepsilon_{t} ; \quad R^{2}=0.59 \\
C A_{i t}=k_{i}+\underset{(0.01)}{0.60} C A_{i t-1}+\varepsilon_{t} ; \quad R^{2}=0.62
\end{gathered}
$$

Under either specification, there is significant AR(1) coefficient on the lagged current account, though with panel fixed effects, the degree of inertia is reduced somewhat. 
But these specifications are, in a sense, incomplete - failing to recognize a common component associated with the particular pattern in the movement of global dispersion over the past several decades. Moreover, the $\beta$-convergence results indicate that countries with non-zero initial NFA positions continue to accumulate assets (liabilities) on a net basis by running current account surpluses (deficits) in subsequent periods. In other words, countries tend to run significant imbalances of the same sign (either positive or negative) as in the past. To introduce this trend feature into the analysis, we include a sign-preserving time trend (sptrend) constructed as follows:

$$
\operatorname{sptrend}_{t}=\operatorname{sign}\left(C A_{t-1}\right) * t ; \text { where } \operatorname{sign}\left(C A_{t-1}\right)=C A_{t-1} /\left|C A_{t-1}\right| \cdot
$$

The time trend specifies increasing surpluses or deficits depending on the sign of the current account in the previous period. Note too that this sign-preserving trend is also broadly consistent with preserving current account adding-up, while a simple time trend is not. ${ }^{15}$ Including this term into the panel fixed effects regression yields:

$$
C A_{i t}=k_{i}+\underset{(0.004)}{0.01} \text { sptrend }_{t}+\underset{(0.01)}{0.59} C A_{i t-1}+\varepsilon_{t} ; R^{2}=0.63
$$

\footnotetext{
${ }^{15}$ Current account adding-up would be more apparent if balances were defined in a common unit, (say) U.S. dollars - but this would raise issues of nominal drift. Using the current account ratio to GDP broadly perserves the level of the current account discrepancy (in percent of GDP) provided that surplus and deficit countries (as respective groups) are of similar economic size.
} 
The trend capturing increasing dispersion is statistically significant $(p$ value $=0.08) .{ }^{16}$ The fit of the equation is marginally improved and the persistence parameter (AR1 coefficient) is smaller, as one would expect. ${ }^{17}$ In other words, some of the observed persistence in external balances appears to reflect an underlying trend phenomenon — a slowly increasing global dispersion. This is perhaps better viewed as an evolving longer-run process occurring over many decades rather than the inertia in external balances seen from year to year.

Taking an average trend estimate over different specifications, one can examine the extent to which the recent increase in the U.S. current account deficit is due to this underlying global trend. Figure 5 shows the observed U.S. current account deficit ratio to GDP (line) and the long-run contributions (bars) that obtain from equation (4), reflecting the common or global trend term on average. Accounting for increasing global dispersion goes part way to explaining the burgeoning U.S. deficit in past years, but clearly the widening imbalance has gone far beyond these considerations. In level terms, the long-run component (adding the

\footnotetext{
${ }^{16}$ Due to the unbalanced panel, the sign-preserving trend coefficient in (4) is estimated for the vast majority (but not all) countries. Including the full sample (which has countries with only few observations at the end of sample) would reduce the coefficient estimate given the accumulated value of the trend term itself. A "resetting" trend for these countries would raise the point estimate. For further sensitivity analysis, see the following footnote.

${ }^{17}$ When the sign-preserving trend is constructed using the contemporaneous rather than lagged current account, the trend coefficient is always substantially larger and highly significant; and the AR1 coefficient is also substantially reduced.But this specification is susceptible to simultaneity issues. Across various specifications and samples, the range of trend estimates is roughly between 0.005 to 0.085 . As a cross-check, the fitted values and implied rate of increase in global dispersion for a given trend estimate is compared to the rates from the non-parametric estimates disscussed earlier.
} 
trend and either a common or country-specific constant) would narrow but not nearly close the "gap" with the observed deficit.

Figure 5. U.S. Current Account, 1960-2004

(in percent of GDP)

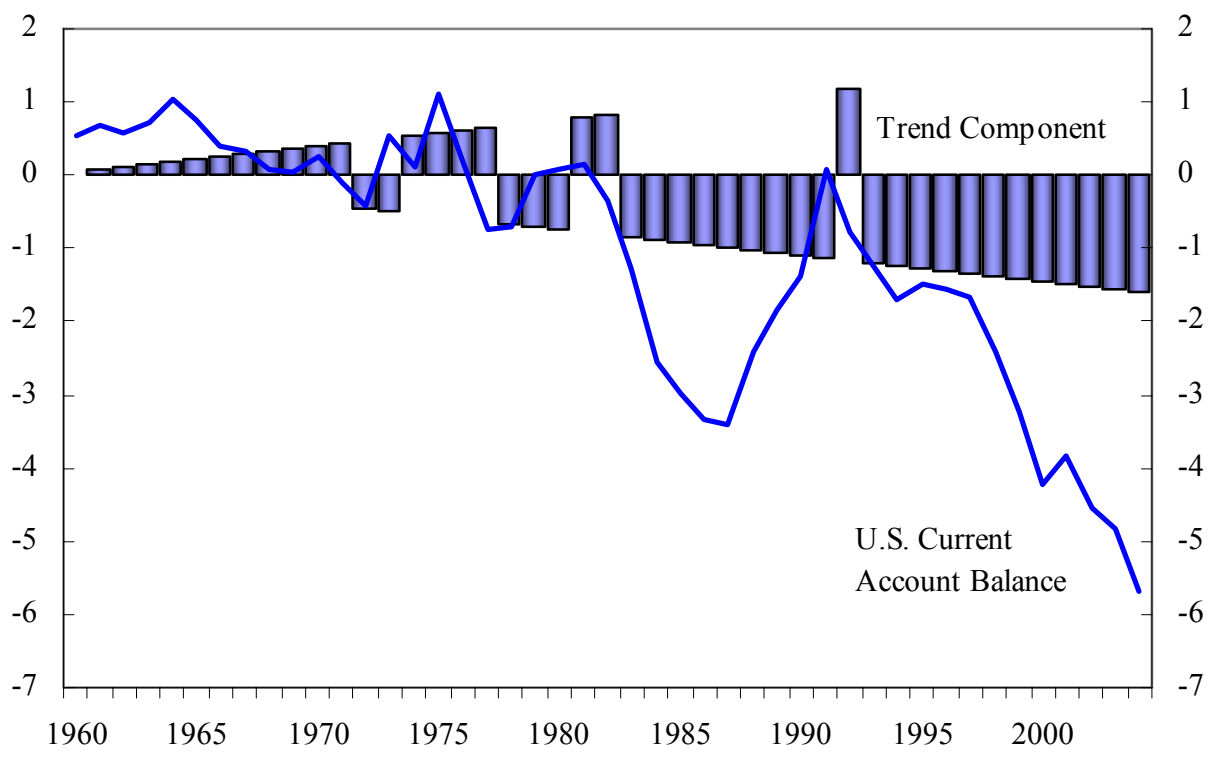

\section{Dispersion, Persistence, and Openness}

We have seen that the cross section dispersion of current accounts has been rising while the time series of current accounts have remained stationary. In particular, equation (4) based on sign-preserving trends suggests that the cross-section distribution of long-run average current accounts (measured by the constant terms in AR(1) regression and the sign-preserving trends) has been spreading out. What are behind these trends? Are they in fact driven by the 
force of globalization, experienced as a rising integration of goods and financial markets across different countries?

We thus consider two economic variables that are likely to affect the behavior of external imbalances: openness to trade and financial flows. We measure trade openness by the ratio of exports and imports to GDP, and financial openness by the Chinn-Ito index, scaled to lie between 0 and 1 (see the appendix for details). As most economies have been opening up and increasing external flows in trade and finance, a deterministic time trend will capture a large part of the common trend toward greater openness. Country-specific measures of openness, however, will help us to extract more information on the role of openness by exploiting different speeds toward openness among countries.

Countries with more open trade regimes would find it easier to sell goods produced beyond the need for domestic consumption and to import goods for which demand exceeds domestic production. The trade imbalance is the aggregate accumulation of such imbalances over the whole economy. A country with more open trade regime will thus be more likely to run a trade imbalance, and also find it easier to finance them given the wider base for international lending and borrowing.

More directly, countries with more open financial account will find it easier to lend or borrow to balance its savings capacity and investment need. In addition to enabling countries to put savings to the most productive use and to finance investment needs in the most 
efficient manner, a greater availability of investment and funding opportunities will tend to stimulate savings and investment, and increase international financial flows further.

To fix ideas on how to incorporate their effects on the dispersion of current accounts, let us consider the following AR(1) representation of the current account of country $i$.

$$
C A_{i t}=\mu_{i}+\beta C A_{i t-1}+\varepsilon_{i t}
$$

Idiosyncratic shocks $\varepsilon_{i t}$ are uncorrelated across countries and time ( $i$ and $t$ ), and have mean zero and unit variance $\left(\sigma^{2}\left(\varepsilon_{i t}\right)=1\right)$, evaluated over $i$ at each point in time. The long-run average current account, $\mu_{i}$, is allowed to differ across countries. Since the current accounts have been found to be stationary with its AR(1) coefficients lying between 0 and 1 , we assume that $0<\beta<1$, and obtain the following MA representation of the current account.

$$
C A_{i t}=\mu_{i}+\sum_{l=0}^{\infty} \beta^{l} \varepsilon_{i t-1}
$$

The global dispersion of current account at time $t$ is

$$
\sigma^{2}\left(C A_{i t}\right)=\sum_{l=0}^{\infty} \beta^{2 l} \sigma^{2}\left(\varepsilon_{i t-l}\right)+\sigma^{2}\left(\mu_{i}\right)=\left(1-\beta^{2}\right)^{-1}+\sigma^{2}\left(\mu_{i}\right)
$$

There are two ways that the global dispersion of current accounts can increase. For one, the cross-section distribution of the long-run average current account can spread out over time, thereby increasing the global dispersion of the current account. Alternatively, a rise in the persistence of current account deviation from its long-run average can increase the observed 
global dispersion of current account as the effect of idiosyncratic shocks die out more slowly. (See Taylor (2001) for suggestive evidence of the latter channel for traditional OECD countries over a span of 100 years.)

We separate these two channels in our estimation. To allow the cross-section distribution to spread out, we construct sign-preserving indicators of openness. When "tradeopen" and “finopen” measure openness in trade and financial accounts, respectively, sign-preserving openness indictors are:

$$
\begin{gathered}
\text { sptradeopen }_{t}=\operatorname{sign}\left(C A_{t-1}\right) * \text { tradeopen }_{t} \\
\text { spfinopen }_{t}=\operatorname{sign}\left(C A_{t-1}\right) * \text { finopen }_{t}
\end{gathered}
$$

This leads to an expanded version of equation (4).

$$
C A_{i t}=\mu_{i}+\beta_{1} \text { sptrend }_{t}+\beta_{2} \text { sptradeopen }_{i t}+\beta_{3} \text { spfinopen }_{i t}+\beta_{4} C A_{i t-1}+v_{t}
$$

To incorporate the effects of openness on the persistence of current accounts, we also estimate a version that includes three additional interaction terms between the lagged current account and these three variables, Here, the sign of current accounts does not matter and lagged current accounts are interacted with the original variables: trend $_{t}$, tradeopen $_{t}$, and finopen $_{t}$. The estimating equation becomes:

$$
\begin{aligned}
& \text { CA }_{i t}=\mu_{i}+\beta_{1} \text { sptrend }_{t}+\beta_{2} \text { sptradeopen }_{i t}+\beta_{3} \text { spfinopen }_{i t}+\beta_{4} C A_{i t-1} \\
& +\beta_{5} C A_{i t-1} * \text { trend }_{t}+\beta_{6} C A_{i t-1} * \text { tradeopen }_{i t}+\beta_{7} C A_{i t-1} * \text { finopen }_{i t}+v_{t}
\end{aligned}
$$


Table 2 reports the results of estimating various versions of this equation on the basis of data for 73 countries whose current account data are available starting in no later than 1975. In the upper panel, the openness in trade and finance was measured as the moving averages of the recent three years. In the lower panel, the openness was measured by the average over the whole sample period.

Columns I and II repeat the regressions that we estimated for the larger and longer sample of countries. The results coincide qualitatively, though with some quantitative difference. As in equation (4), countries have been able to run larger current imbalances over time, and the persistence of current account imbalances declines a little as the estimating equation incorporates the trend increase in dispersion.

In columns III and VI (in the lower panel), we introduce the openness measures as structural determinants that enable countries to run larger current account imbalances. The results indicate that the time trend must have reflected the effect of openness. In column III, the coefficient on time trend turns negative, while the coefficients on trade and financial openness are numerically large and statistically significant. In column VI, trade openness remains statistically significant while time trend and financial openness lose statistical significance. Between column III and column VI, using sample averages appears to have reduced a large part of variation in financial openness which has gone through particularly rapid changes since the late-1980s. In terms of their effect on persistence, the inclusion of openness measures further reduces the persistence parameter, again less strongly in column VI which uses the average measures of openness. 
We examine the effects of these variables on the persistence parameter (AR1 coefficient). No strong prior applies to the direction of their effects. It is tempting to presume that a greater availability of financing will lead to a higher persistence of the shocks to current account, for countries will be able to finance their current account deficits more easily. However, the relaxation of financial constraints can also lead countries to fund their needs more quickly but at a larger scale. For example, a Solovian developing country that needs a large development financing will borrow a large amount in the beginning, if she can. Such response will imply a lower persistence of current account shocks and a larger dispersion of current account imbalances across countries. To summarize, a larger value of the persistence parameter is consistent with a more gradual financing, while a smaller value is consistent with a more rapid financing.

Starting with a regression that only uses time trend (column IV), the persistence parameter is found to have been declining over time. Countries are also found to have been able to run larger current account imbalances_-deficit or surplus - over time. When we allow openness measures to affect persistence (columns V and VII), we uncover an interesting contrast in the effects of trade and financial openness. Trade openness, if any, increases the persistence of current account imbalance while financial openness reduces the persistence. And the effect of financial openness remains statistically significant even when the openness is measured by the average over the whole sample period. Most interesting is the joint effect of financial openness on persistence and the dispersion of long-run average current accounts. A financially more open — better integrated - country appears to be able to run a larger 
imbalance, but over a shorter duration. This is consistent with the possibility that financially better integrated countries can meet its international financing or investment need more quickly.

These findings are confirmed in Table 3, where the same relationships as in Table 2 were estimated by popular GMM estimates, considering the presence of lagged dependent variables on the right hand side. Trade openness is found to increase the persistence of current account imbalances, whereas financial openness is found to clearly decrease the persistence of current account imbalances.

\section{Concluding Remarks}

Examining current accounts for a wide spectrum of countries over the past four and a half decades, we can summarize our key findings or "stylized facts" as follows:

- The universe of current accounts has been expanding over the past half century. Based on a variety of measures and methodologies, the global constellation of external current account positions has markedly widened over time. While dispersion can vary significantly from year to year-ostensibly in response to large international shocks, there is a steady, underlying rate of expansion of around 2 to 3 percent per year.

- In other words, in a context where global gross financial flows have grown rapidly, net flows have also increased (on a sustained basis) to individual countries. And sign reversals in the current account are occasional, but not frequent. Reflecting this 
persistence in current account imbalances, countries that have run larger external imbalances in the past also tend to run subsequent, larger imbalances (of the same sign), suggesting a extenuation of international lending or borrowing patterns.

However, the underlying, long-run trend toward greater global dispersion suggests that inertia in current accounts from year to year may be overstated by simple estimates of persistence.

- Rising dispersion is also found to be closely associated with increasing financial integration of the world economy, among other things. At the same time, individual current account series and changes in net foreign assets (as ratios to GDP) are found to be stationary (albeit persistent), indicating that while dispersion is rising, basic intertemporal resource constraints are not likely violated for individual countries.

- Global imbalances though have run well ahead of underlying dispersion trends. The recent acceleration of external positions in major countries (including the United States) is clearly not fully accounted for by the trend behavior exhibited by the universal expansion.

From an economic standpoint, the results lend support to recent views that some, though not all, of the large global current account imbalances are due to the ongoing integration of the world economy. In particular, it is not surprising that we would see, in an increasingly integrated global economy, higher levels of current account deficits (including in the United States) and surpluses in key partner countries. The other side of this trend is the likely weakening in the statistical hold of the Feldstein-Horioka results. However, we also find that the underlying pace of the increase in global dispersion is not as fast as sometimes claimed 
and has bounds, indicating that a sizable part of today's global imbalances is likely in excess (relative to the underlying trend) and would probably be unwound to a significant degree. Some movements in that direction appear to have finally started in the United States, while the counterpart movements are less evenly distributed. 


\section{REFERENCES}

Bernanke, Ben, 2005, “Remarks at the Homer Jones Lecture.” St. Louis, MO, April 14, 2005.

Blanchard, Olivier J. and Giavazzi, Francesco, "Current Account Deficits in the Euro Area. The End of the Feldstein Horioka Puzzle?" (2002)

Blanchard, Olivier, Francesco Giavazzi, and Filipa Sa, The U.S. Current Account and the Dollar, NBER Working Paper No 11137, 2005/ BPEA 2006.

Bohn, Henning, 2005, “Are Stationarity and Cointegration Restrictions Necessary for the Intertemporal Budget Constraint?" mimeo, Univeristy of California at Santa Barbara.

Campbell, John Y. and Pierre Perron, "Pitfalls and Opportunities: What Macroeconomists Should Know about Unit Roots," NBER Working Paper T0100 (April).

Chinn, Menzie D. and Hiro Ito, 2005, "What Matters for Financial Development? Capital Controls, Institutions, and Interactions," Journal of Development Economics (forthcoming).

Chinn, Menzie D. and Jaewoo Lee, 2005, “Three Current Account Balances: A SemiStructuralist Interpretation,” NBER Working Paper .

Faruqee, H., D. Laxton, D. Muir and P. Pesenti, 2006a, "Smooth Landing or Crash? Model-based Scenarios of Global Current Account Rebalancing" =in R. Clarida (ed.), G7 Current Account Imbalances: Sustainability and Adjustment, NBER conference volume: University of Chicago Press.

Faruqee, H., D. Laxton, D. Muir and P. Pesenti, 2006b, "Would Protectionism Defuse Global Imbalances and Spur Economic Activity? A Scenario Analysis," NBER Working Paper 12704 (November).

Feldstein, Martin and Charles Horioka, 1980, "Domestic Saving and International Capital Flows", Economic Journal 90: 314-329

Ghironi, Fabio, Jaewoo Lee and Alessandro Rebucci, 2007 "The Valuation Channel of External Adjustment," NBER WP 12937.

Gourinchas, Pierre-Olivier and Helene Rey, 2005, "From World Banker to World Venture Capitalist: The U.S. External Adjustment and the Exorbitant Privilege." Paper presented at the NBER conference, "G-7 Current Account Imbalances: Sustainability and Adjustment," Newport, June 1-2.

Greenspan, Alan, 2005, “Current Account.” Presentation at Advancing Enterprise 2005 Conference, London, February 4, 2005. 
IMF, 2005, World Economic Outlook (Washington, D.C., September).

Kose, M. Ayhan, Eswar S. Prasad, Kenneth Rogoff and Shang-Jin Wei, 2006, "Financial Globalization: A Reappraisal," IMF Working Paper 06/189.

Kraay, Art and Jaume Ventura, 2000, "Current Accounts in Debtor and Creditor Countries," Quarterly Journal of Economics.

Krugman, Paul, 1991. "Introduction,” in: Bergsten, C. F. (Eds.), International Adjustment and Financing: The Lessons of 1985-1991, Institute for International Economics, Washington, D.C., pp. 3-12.

Lane, Philip and Gian Maria Milesi-Ferretti, 2001, "The External Wealth of Nations: Measures of Foreign Assets and Liabilities in Industrial and Developing Countries" Journal of International Economics 55 no. 2, December 2001, 263-94.

Lane, Philip and Gian Maria Milesi-Ferretti, 2007, "The External Wealth of Nations Mark II: Revised and Extended Estimates of Foreign Assets and Liabilities," (joint with Philip Lane), Journal of International Economics 73 (November 2007), 223-250.

Marquez, Jaime and Workman, Lisa, 2001, "Modeling the IMF's Statistical Discrepancy in the Global Current Account", IMF Staff Papers, 2001, vol. 48, issue 3 (September).

Obstfeld, Maurice, and Kenneth Rogoff, 2004, "The Unsustainable US Current Account Position Revisited," NBER Working Paper No. 10869.

Prasad, Eswar S., Kenneth Rogoff, Shang-Jin Wei, and M. Ayhan Kose, 2003, Effects of Financial Globalization on Developing Countries: Some Empirical Evidence, IMF Occasional Paper No. 220 (Washington: International Monetary Fund).

Taylor, Alan, 2001, “A Century of Current Account Dynamics," Journal of International Money and Finance.

Trehan, Bharat and Carl E. Walsh, 1991, "Testing Intertemporal Budget Constraints: Theory and Application to U.S. Federal Budget and Current Account Deficits," Journal of Money, Credit, and Banking, 23 (2), pp. 206-23. 


\section{Appendix I. Data Description}

The main variable is the ratio of the current account to the GDP, both of which were obtained from various issues of International Financial Statistics (IMF) and World Development Indicator (World Bank). The capital account liberalization index was developed by Chinn and Ito (2005), and is the first principal component of several variables that reflect the ease of cross-border financial transactions. In our estimation, the index was normalized to take a value between 0 and 1, increasing with the liberalization of capital account regime. For each value of Chinn-Ito index $C I_{i t}$, our indicator is defined as follows.

$$
\text { finopen }_{i t}=\frac{C I_{i t}-\operatorname{Min}\left\{C I_{i t}\right\}}{\operatorname{Max}\left\{C I_{i t}\right\}-\operatorname{Min}\left\{C I_{i t}\right\}}
$$

Descriptive statistics for the ratio of the current account to GDP show:

- Unconditional means in more than three-quarters (74 out of 94) of the countries statistically different from zero ( $\mathrm{p}=0.05$ or higher); see Table A0.

- $\quad$ Conditional means in more than half of the countries (64 out of 94), based country constants (i.e., fixed effects), are significantly different from $0(\mathrm{p}=0.10$ or higher).

- $\quad$ For higher moments, evidence of skewness or excess kurtosis ("fat tails") was found in 28 out of 94 countries (i.e., 30 percent of sample). 


\section{Appendix II. Alternative Measures of External Positions and Their Behavior}

A related but distinct measure is the change in net foreign assets (NFA). It essentially differs from the current account by the amount of capital gains (valuation change), which is driven by asset price fluctuations, including exchange rate variations. Since these asset price movements are broadly described as a random walk, the change in NFA will contain a much larger white-noise component and exhibit smaller persistence than the current account. This is indeed confirmed by the data, as summarized in the following two charts. Note that due to data limitations regarding NFA, the sample size is smaller.

First, the change in NFA (in percent of GDP) is subjected to the same battery of stationarity and unit root tests as for the current account, summarized in Figure 4. The test results uniformly show a higher rejection rate of non-stationarity. See Figure A1. Second, for the change in the ratio of NFA to GDP-i.e., $\Delta(\mathrm{NFA} / \mathrm{y})$ - the indications toward stationarity are even stronger; see Figure A2. Changes in the ratio also include a growth term (related to the change in the scaling variable GDP). This helps toward finding stationarity in the ratio given that GDP (i.e., the denominator) is growing over time. Excluding the growth factor term (by considering $\triangle \mathrm{NFA} / \mathrm{y}$ ) weakens the stationarity finding, but does not overturn it. That is, the $\triangle$ NFA concept appears to be much more stationary (less persistent) series than CA. 
Figure A1. Unit Root Tests Rejection Rates

(variable $=\Delta \mathrm{NFA} / \mathrm{GDP} ;$ in percent $)$

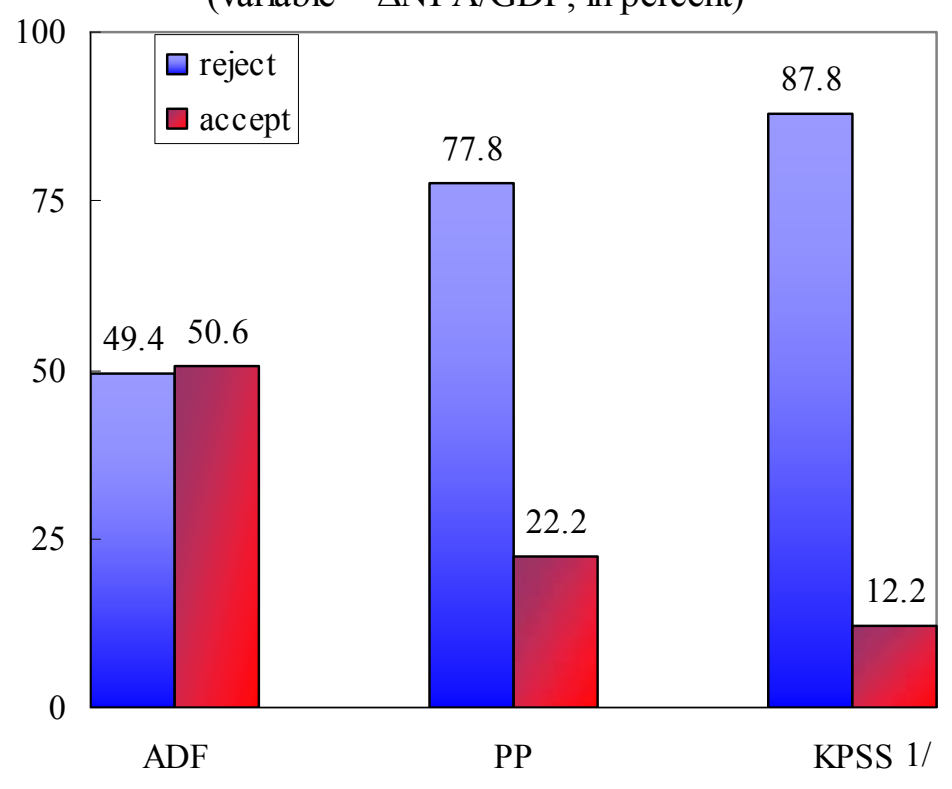

1/ Variable is change in NFA as a ratio to GDP; for KPSS test, failure to reject stationarity reported as rejection of unit root in the graph. $\mathrm{N}=81$.
Figure A2. Unit Root Test Rejection Rates

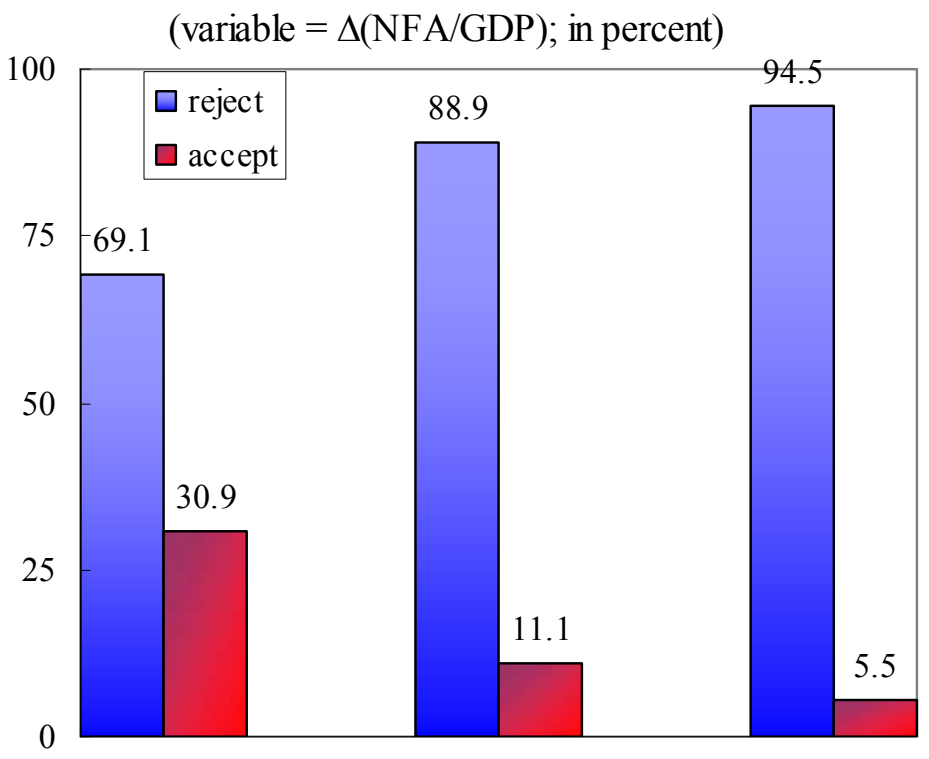

$\mathrm{ADF}$
PP

1/ Variable is change in NFA-to-GDP ratio; for KPSS test, failure to reject stationarity reported as rejection of unit root in the graph. $\mathrm{N}=81$.

\section{Appendix III. Expanding Dispersion and Financial Market Integration}

Considering the pivotal role of the financial openness in expanding the global dispersion of current accounts, we present an illustrative (steady-sate) model where the ongoing integration in international financial markets increases the global dispersion of current accounts. Some form of heterogeneity is the necessary condition for global dispersion, and we introduce the heterogeneity in the discount rate. Combined with a small cost of financial intermediation, which represents financial market friction, we generate a non-degenerate steady-state distribution of net foreign assets. Further introducing growth in aggregate output, we show 
that the global dispersion of current accounts rises, as the cost of financial intermediation falls. And we assume a deterministic world. ${ }^{18}$

World economy is assumed to be composed of $\mathrm{N}$ open economies, each of which commands a fixed stream of endowment $\left(y_{i}\right)$, and has an identical utility function $u\left(c_{i t}\right)$ but with a heterogeneous discount rate $\left(\beta_{i}\right)$. The heterogeneity in the discount rate gives rises to international lending and borrowing (thus current account imbalances). It is further assumed that countries incur a financial transaction cost when they lend or borrow. The period-byperiod budget constraint is written as:

$$
a_{i t+1}=\left(1+r_{t}\right) a_{i t}-c_{i t}+y_{i t}-\frac{\gamma}{2}\left(a_{i t}\right)^{2}+\eta\left(a_{i t}\right)
$$

where $a_{i t}$ denotes the net foreign assets of country $i$, and $r_{t}$ the world interest rate. The financial transaction cost, $\frac{\gamma}{2}\left(a_{i t}\right)^{2}$, captures the cost needed to maintain a non-zero international asset position. ${ }^{19}$ The quadratic form is akin to the adjustment cost widely used in the macroeconomic literature, and is assumed to be the fee paid to competitive financial

${ }^{18}$ In deterministic setup, the ratio of the current account to GDP has a well-defined relationship to the steady-state ratio of NFA to GDP. In stochastic setting, stationary shocks to the current account (and change in NFA) will have a non-stationary effect on NFA, and the stochastic steady-state relationship between the current account and NFA remains unclear.

19 This transaction cost can be defined in terms of percent of GDP, to capture the idea that economic and financial development would lower the financial transaction cost as a share of GDP. That assumption determines the steady-state value of the ratio of the NFA to GDP, and is discussed in Ghironi et. al (2005). 
intermediaries when international financial position is adjusted away from the zero balance. The fees paid to competitive intermediaries are distributed back to each country $\left(\eta\left(a_{i t}\right)=\frac{\gamma}{2}\left(a_{i t}\right)^{2}\right)$ ex post, and thus financial frictions affect the ex-ante decision making of each country without draining global resources.

The first condition for each country's consumption-saving choice is:

$$
\left(\beta_{i}\right)^{t+1} u^{\prime}\left(c_{i t+1}\right)=\left(\beta_{i}\right)^{t} u^{\prime}\left(c_{i t}\right)\left(1+r_{t}-\gamma a_{i t}\right)
$$

In the steady state, $c_{i t+1}=c_{i t}=\bar{c}_{i}$, and equation (7) simplifies to $\beta_{i}=1+r-\gamma \bar{a}_{i}$ and the net foreign asset position is determined by the difference between the world interest rate and the subjective discount rate:

$$
\bar{a}_{i}=\frac{1}{\gamma}\left(1+r-\frac{1}{\beta_{i}}\right)
$$

The world interest rate is determined at a level that equates the global demand and supply of assets: $\sum_{i=1}^{N} \bar{a}_{i}=0$ :

$$
1+r=\sum_{i=1}^{N} \frac{1}{\beta_{i}}
$$

In a no-growth economy just described, the steady-state current account remains in zero balance and there is no dispersion in current accounts. Introducing economic growth leads to a steady-state dispersion in current accounts. Now assume that each country's population grows at the same rate $g$. The aggregate output of a country at time $t$ becomes: 
$Y_{i t}=(1+g)^{t} \bar{y}_{i}$, normalizing the time- 0 population at unity. Denoting the aggregate net

foreign assets by a capitalized letter, $A_{i t}$, the change in the ratio of net foreign assets to GDP can be rewritten in terms of the current account as follows.

$$
\frac{A_{i t+1}}{Y_{i t+1}}-\frac{A_{i t}}{Y_{i t}}=\frac{A_{i t+1}}{Y_{i t+1}}[1-(1+g)]+\frac{A_{i t+1}-A_{i t}}{Y_{i t}}=-g \frac{A_{i t+1}}{Y_{i t+1}}+\frac{C A_{i t}}{Y_{i t}}
$$

In the steady state with the constant ratio of the aggregate net foreign assets to GDP,

$$
\overline{\left(\frac{C A_{i}}{Y_{i}}\right)}=g \overline{\left(\frac{A_{i}}{Y_{i}}\right)}=g \bar{a}_{i}=\frac{g}{\gamma}\left[\left(\sum_{i=1}^{N} \frac{1}{\beta_{i}}\right)-\frac{1}{\beta_{i}}\right]
$$

A tighter integration of international financial markets is represented as a decline in $\gamma$, which lowers the cost of international financial transactions. This will increase the dispersion in the ratio of current account to GDP. 
Table 1. Stationarity of Current Accounts (current accounts in percent of GDP)

[To be updated]

Panel Unit Root Test

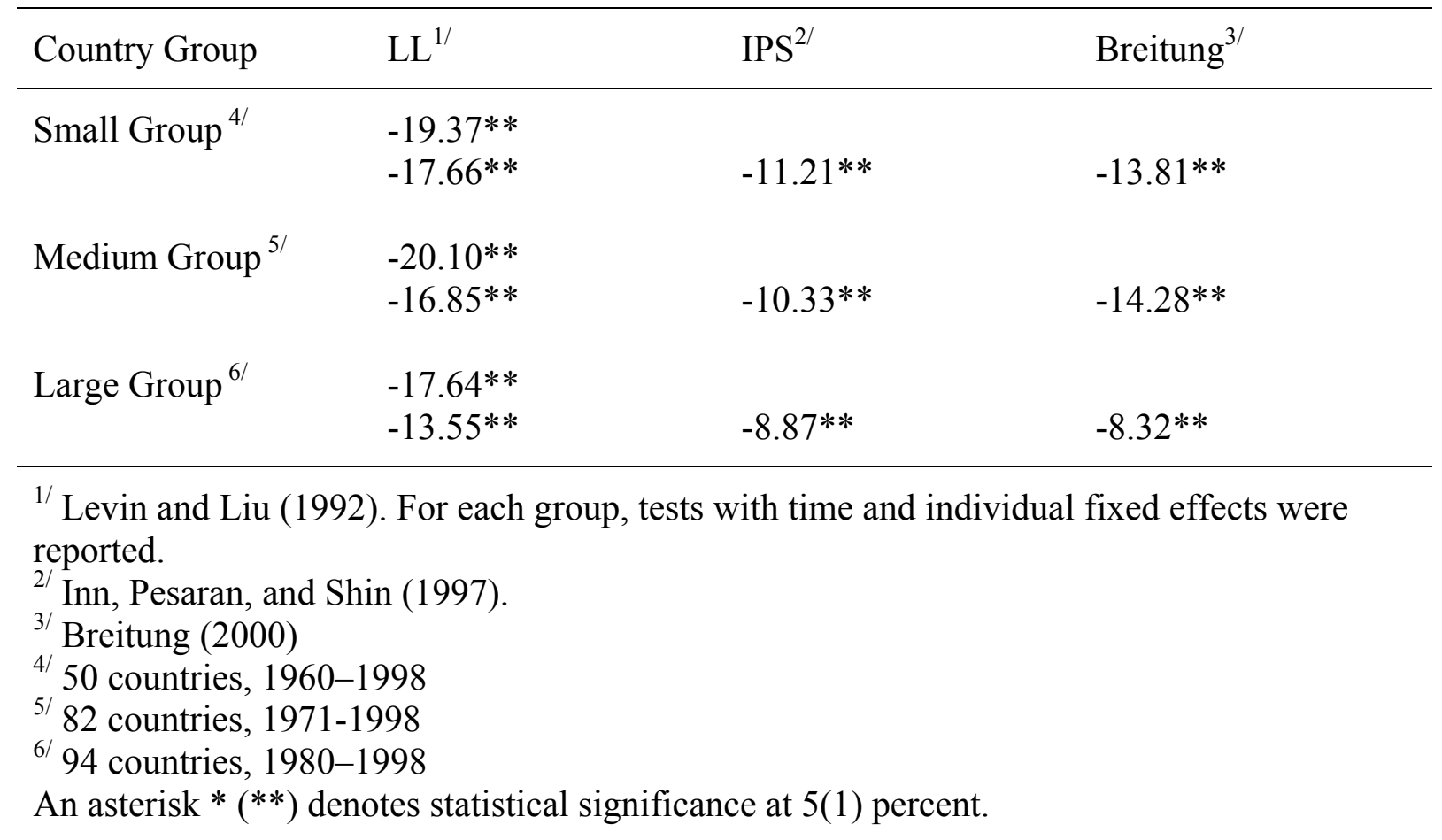


Table 2. Evolution of Current Account Dynamics

(1971-2004)

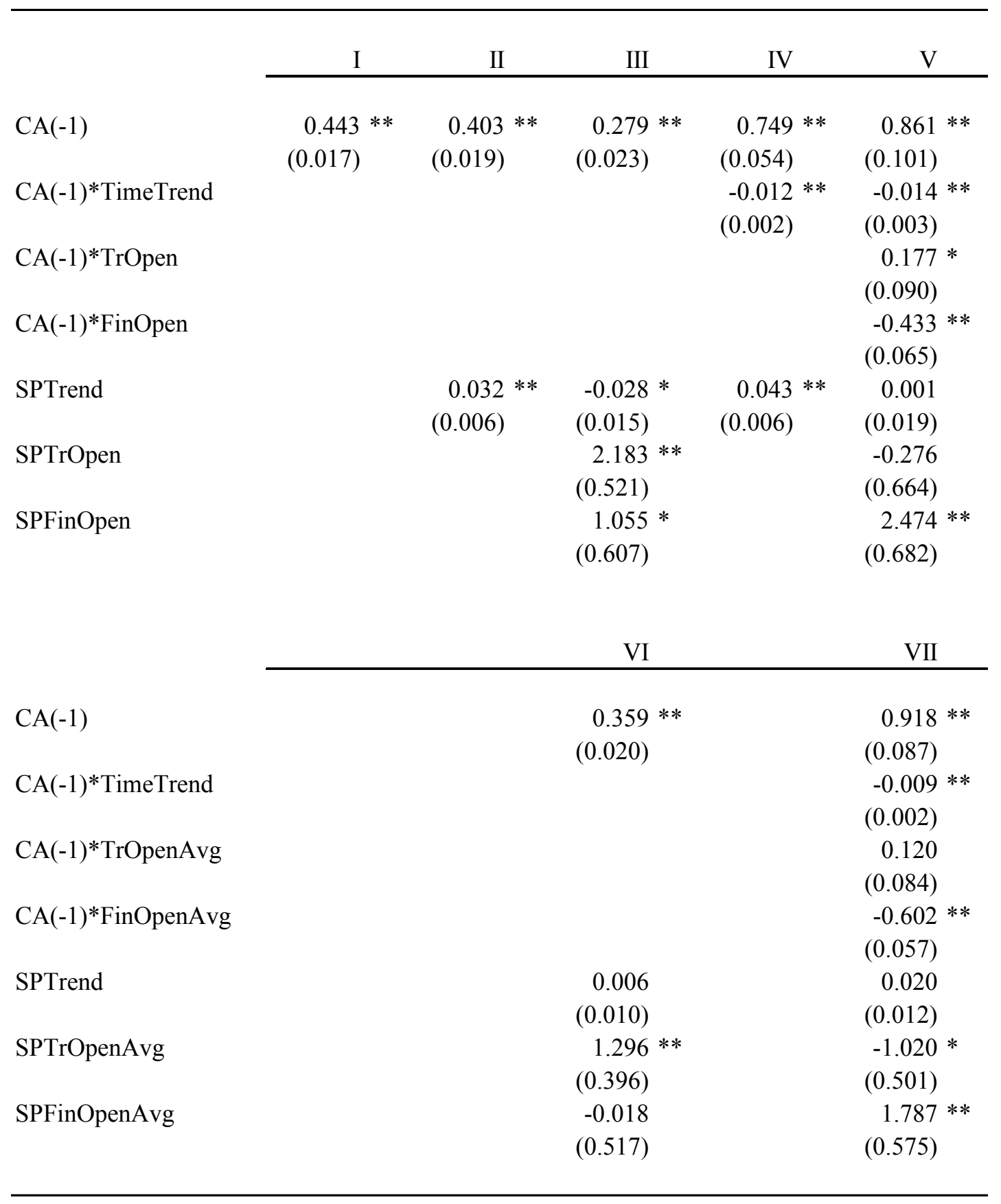

Statistically significant at 5 percent $(* *)$ and 10 percent $(*)$.

All regressions included country fixed effects.

Based on the sample of 73 countries whose current account data were available starting before 1975 . 
Table 3. Evolution of Current Account Dynamics -- GMM Estimates (1971-2004)

\begin{tabular}{|c|c|c|c|c|c|}
\hline & I & II & III & IV & V \\
\hline $\mathrm{CA}(-1)$ & $\begin{array}{l}0.341 * * \\
(0.001)\end{array}$ & $\begin{array}{l}0.290 \text { ** } \\
(0.055)\end{array}$ & $\begin{array}{l}0.188 \text { ** } \\
(0.002)\end{array}$ & $\begin{array}{l}1.038^{* *} \\
(0.010)\end{array}$ & $\begin{array}{l}1.340 \text { ** } \\
(0.016)\end{array}$ \\
\hline CA(-1)*TimeTrend & & & & $\begin{array}{l}-0.027 \text { ** } \\
(0.002)\end{array}$ & $\begin{array}{l}-0.023 \text { ** } \\
(0.001)\end{array}$ \\
\hline CA(-1)*TrOpen & & & & & $\begin{array}{r}0.020 \\
(0.035)\end{array}$ \\
\hline CA(-1)*FinOpen & & & & & $\begin{array}{l}-0.544 * * \\
(0.018)\end{array}$ \\
\hline SPTrend & & $\begin{array}{l}0.055^{* *} \\
(0.001)\end{array}$ & $\begin{array}{l}-0.094^{* *} \\
(0.005)\end{array}$ & $\begin{array}{l}0.081 \text { ** } \\
(0.002)\end{array}$ & $\begin{array}{l}-0.011 * * \\
(0.005)\end{array}$ \\
\hline SPTrOpen & & & $\begin{array}{l}4.791 \text { ** } \\
(0.181)\end{array}$ & & $\begin{array}{r}-0.217 \\
(0.273)\end{array}$ \\
\hline SPFinOpen & & & $\begin{array}{l}3.454 * * \\
(0.033)\end{array}$ & & $\begin{array}{l}3.960 * * \\
(0.215)\end{array}$ \\
\hline & & & VI & & VII \\
\hline $\mathrm{CA}(-1)$ & & & $\begin{array}{l}0.180 \text { ** } \\
(0.002)\end{array}$ & & $\begin{array}{c}0.912 \text { ** } \\
(0.014)\end{array}$ \\
\hline CA(-1)*TimeTrend & & & & & $\begin{array}{l}-0.021 * * \\
(0.001)\end{array}$ \\
\hline CA(-1)*TrOpenAvg & & & & & $\begin{array}{l}0.423 \text { ** } \\
(0.010)\end{array}$ \\
\hline CA(-1)*FinOpenAvg & & & & & $\begin{array}{l}-0.591 \text { ** } \\
(0.010)\end{array}$ \\
\hline SPTrend & & & $\begin{array}{l}-0.110 * * \\
(0.002)\end{array}$ & & $\begin{array}{l}0.041 \text { ** } \\
(0.009)\end{array}$ \\
\hline SPTrOpenAvg & & & $\begin{array}{l}4.963 * * \\
(0.148)\end{array}$ & & $\begin{array}{l}-1.973 * * \\
(0.221)\end{array}$ \\
\hline SPFinOpenAvg & & & $\begin{array}{l}3.667 * * \\
(0.070)\end{array}$ & & $\begin{array}{l}4.294 \text { ** } \\
(0.120)\end{array}$ \\
\hline
\end{tabular}

Statistically significant at 5 percent $(* *)$ and 10 percent $\left(^{*}\right)$.

All regressions included country fixed effects.

Based on the sample of 73 countries whose current account data were available starting before 1975 . 
Table A1. Current Account Balances (in percent of GDP), 1960-2004 Stationarity Tests (under revision)

\begin{tabular}{|c|c|c|c|c|c|c|c|}
\hline Country & $\underline{\mathrm{ADF} 1 /}$ & $\underline{\mathrm{PP}} 2 /$ & $\underline{\text { KPSS } 3 /}$ & Country & $\underline{\mathrm{ADF} 1 /}$ & $\underline{\text { PP 2/ }}$ & $\underline{\text { KPSS } 3 /}$ \\
\hline United States & 0.21 & -0.15 & $1.16^{*}$ & Argentina & -2.24 & $-3.45^{*}$ & 0.13 \\
\hline United Kingdom & $-3.11 *$ & -2.59 & 0.45 & Taiwan & -1.70 & -2.60 & 0.400 \\
\hline Austria & $-3.03 *$ & $-3.04 *$ & 0.12 & Côte d'Ivoire & -1.47 & -2.39 & 0.32 \\
\hline Denmark & -2.18 & -1.97 & $0.85^{*}$ & Kenya & -2.40 & $-3.95^{*}$ & 0.30 \\
\hline Germany & -2.15 & -2.42 & 0.08 & Uruguay & -2.38 & $-3.24 *$ & 0.16 \\
\hline Italy & -2.90 & $-3.05^{*}$ & 0.21 & Algeria & -0.75 & -2.64 & $0.62 *$ \\
\hline Norway & -1.76 & -1.46 & $0.97 *$ & Mauritius & -2.52 & $-3.47 *$ & 0.15 \\
\hline Sweden & -0.07 & -0.24 & $0.56^{*}$ & Benin & -2.47 & $-4.84 *$ & 0.10 \\
\hline Switzerland & -0.36 & -1.09 & $1.40 *$ & Togo & -2.29 & $-4.05^{*}$ & 0.43 \\
\hline Canada & -1.06 & -1.81 & $0.49 *$ & Indonesia & -1.67 & -2.47 & $0.52 *$ \\
\hline Japan & -1.90 & -2.74 & $0.98 *$ & Thailand & -2.05 & -2.14 & 0.43 \\
\hline Finland & -1.39 & -1.58 & $0.66^{*}$ & Uganda & -1.49 & $-4.11^{*}$ & $0.94 *$ \\
\hline Greece & -2.69 & $-3.21 *$ & 0.22 & France & -2.31 & -2.77 & $0.53 *$ \\
\hline Iceland & $-3.23^{*}$ & $-4.72 *$ & 0.10 & Netherlands & -2.75 & $-3.07 *$ & 0.25 \\
\hline Ireland & -1.64 & -2.08 & $0.58 *$ & New Zealand & $-3.05^{*}$ & $-3.41^{*}$ & 0.11 \\
\hline Spain & $-3.92 *$ & $-3.25^{*}$ & 0.25 & Saudi Arabia & -1.25 & -2.14 & 0.40 \\
\hline Turkey & -2.32 & $-4.75^{*}$ & 0.13 & Pakistan & -0.87 & -2.68 & $0.55^{*}$ \\
\hline Australia & -1.60 & -2.80 & $0.87^{*}$ & Gabon & -1.81 & $-3.37^{*}$ & 0.19 \\
\hline South Africa & $-3.57 *$ & $-3.48^{*}$ & 0.17 & Niger & -2.83 & -2.56 & $0.47^{*}$ \\
\hline Bolivia & -1.85 & $-4.43^{*}$ & 0.24 & Senegal & -2.24 & -2.76 & 0.32 \\
\hline Brazil & -2.05 & -2.20 & 0.13 & Gambia & -2.64 & -2.88 & 0.20 \\
\hline Chile & -1.41 & $-3.08^{*}$ & 0.21 & Madagascar & -2.67 & $-5.10^{*}$ & 0.11 \\
\hline Costa Rica & -2.19 & $-3.04 *$ & 0.46 & Hungary & -1.53 & $-3.18^{*}$ & 0.33 \\
\hline Dominican Republic & -2.44 & $-4.73 *$ & 0.31 & Congo & -0.91 & $-3.16^{*}$ & 0.33 \\
\hline El Salvador & $-3.42 *$ & $-5.51 *$ & 0.07 & Romania & -1.18 & -2.35 & 0.39 \\
\hline Guatemala & -2.13 & $-4.15^{*}$ & $1.09 *$ & Portugal & -1.31 & -2.90 & 0.18 \\
\hline Haiti & -1.84 & $-2.31 *$ & 0.17 & Papa New Guinea & -1.02 & -2.24 & 0.42 \\
\hline
\end{tabular}

Table A1 (continued). Current Account Balances (in percent of GDP), 1960-2004 Stationarity Tests (under revision)

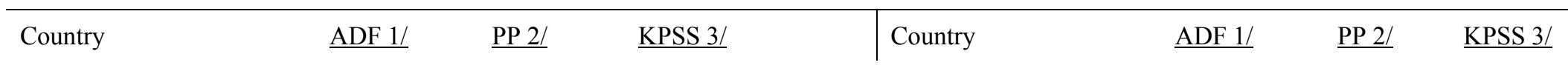


$-38-$

\begin{tabular}{|c|c|c|c|c|c|c|c|}
\hline Honduras & -2.87 & $-3.57^{*}$ & 0.28 & Bangladesh & -1.48 & -2.62 & $0.85^{*}$ \\
\hline Mexico & $-3.28^{*}$ & $-3.49 *$ & 0.06 & Mauritania & -1.44 & -2.48 & 0.41 \\
\hline Panama & -2.22 & $-2.99 *$ & 0.26 & Oman & -1.56 & $-3.81 *$ & 0.24 \\
\hline Paraguay & -2.75 & $-2.98 *$ & 0.20 & Burkina Faso & -0.45 & -2.11 & $0.56^{*}$ \\
\hline Peru & $-4.29 *$ & $-3.80 *$ & 0.26 & Bahrain & $-3.35^{*}$ & -2.79 & 0.18 \\
\hline Venezuela & -0.07 & $-4.27 *$ & 0.20 & Kuwait & -2.55 & $-4.69 *$ & 0.23 \\
\hline Jamaica & -2.28 & $-3.32 *$ & 0.10 & Bostwana & -1.91 & -2.57 & $0.61 *$ \\
\hline Trinidad y Tobago & $-3.06^{*}$ & $-3.02 *$ & 0.36 & Lesotho & -1.53 & -2.53 & 0.40 \\
\hline Israel & -2.08 & $-3.19 *$ & 0.39 & Ecuador & -2.45 & $-4.08 *$ & 0.41 \\
\hline Jordan & $-3.40^{*}$ & $-4.55^{*}$ & 0.11 & Nepal & -0.67 & -1.64 & 0.28 \\
\hline Egypt & -1.73 & -2.26 & $0.68 *$ & Poland & -1.80 & -2.71 & 0.32 \\
\hline Myanmar & -2.63 & $-3.04 *$ & 0.42 & Cameroon & -2.00 & $-4.67 *$ & 0.41 \\
\hline Sri Lanka & $-3.04 *$ & $-3.73 *$ & 0.22 & C. African Rep. & -2.82 & $-5.64 *$ & 0.14 \\
\hline India & -2.11 & -2.32 & 0.18 & Zimbabwe & -2.65 & $-3.41 *$ & 0.08 \\
\hline Korea & -1.28 & -2.81 & $0.68 *$ & Cambodia & $-3.47 *$ & $-3.83 *$ & 0.09 \\
\hline Philippines & -1.70 & -2.43 & 0.26 & Lao P.D. Rep. & $-3.40^{*}$ & -2.86 & 0.13 \\
\hline Ghana & -2.25 & $-4.26^{*}$ & 0.15 & Namibia & $-3.12 *$ & $-4.39 *$ & 0.41 \\
\hline Morocco & -1.46 & -2.35 & 0.34 & Albania & -1.88 & $-4.05^{*}$ & $0.49 *$ \\
\hline Nigeria & -2.44 & $-4.86^{*}$ & 0.20 & Bulgaria & -1.44 & $-3.09 *$ & 0.43 \\
\hline Sudan & -1.81 & $-3.43^{*}$ & 0.41 & China P.R.: Mainland & -1.81 & -2.74 & 0.41 \\
\hline Tunisia & $-3.12 *$ & $-3.14^{*}$ & 0.27 & Mongolia & -1.47 & -1.27 & $0.61 *$ \\
\hline Colombia & $-3.64 *$ & $-3.44 *$ & 0.05 & Moldova & -1.78 & $-3.08 *$ & 0.13 \\
\hline Hong Kong & -2.48 & $-3.19 *$ & 0.29 & Russia & -1.01 & -1.72 & 0.40 \\
\hline Malaysia & -2.24 & -2.46 & 0.28 & & & & \\
\hline
\end{tabular}

1/ Augmented Dickey-Fuller $t$-test statistic for unit root against level stationary alternative; lag length chosen based on Schwarz BIC.

2/ Phillips-Perron $Z_{\mathrm{t}}$ test statistic for unit root against level stationary alternative.

3/ Kwiatowski, Phillips, Schmidt \& Shin (1992) $\eta(\mu)$ test statistic for level stationarity against non-stationary alternative. 
Table A2. Current Account Balances (in percent of GDP), 1960-2004

Autoregressive Coefficients (under revision)

\begin{tabular}{|c|c|c|c|c|c|c|c|c|c|}
\hline Country & $\underline{\mathrm{AR} 15 /}$ & $\underline{\mathrm{R}^{2}}$ & $\underline{\mathrm{LM}}[4] 6 /$ & $\underline{\text { Stability } 7 /}$ & Country & $\underline{\text { AR1 5/ }}$ & $\underline{\mathrm{R}^{2}}$ & $\underline{\mathrm{LM}}[4] 6 /$ & $\underline{\text { Stability } 7 /}$ \\
\hline & & & & & & 0.78 & & & \\
\hline United States & 1.04 & & 3.65 & 0.08 & Panama & & & 1.69 & 0.07 \\
\hline United Kingdom & 0.61 & & 5.15 & 0.12 & Paraguay & 0.71 & & 7.41 & 0.07 \\
\hline Austria & 0.61 & & 9.22 & 0.03 & Peru & 0.57 & & 8.45 & 0.15 \\
\hline Belgium-Luxembourg & 0.83 & & 5.00 & 0.14 & Venezuela & 0.18 & & $8.34 *$ & 0.10 \\
\hline Denmark & 0.60 & & 4.34 & 0.10 & Jamaica & 0.61 & & 3.16 & 0.15 \\
\hline Germany & 0.50 & & $11.54^{*}$ & 0.11 & Trinidad-Tobago & 0.75 & & 4.63 & 0.14 \\
\hline Italy & 0.57 & & 4.61 & 0.09 & Iran & 0.10 & & 2.88 & 0.18 \\
\hline Norway & 0.70 & & 4.45 & 0.06 & Israel & 0.63 & & $12.08^{*}$ & 0.08 \\
\hline Sweden & 0.78 & & 4.98 & 0.09 & Jordan & 0.23 & & 2.46 & 0.21 \\
\hline Switzerland & 0.72 & & $17.85^{*}$ & 0.37 & Egypt & 0.74 & & 2.42 & 0.04 \\
\hline Canada & 0.68 & & 2.10 & 0.08 & Myanmar & 0.62 & & 2.65 & 0.08 \\
\hline Japan & 0.48 & & $14.10 * *$ & 0.39 & Sri Lanka & 0.57 & & 3.40 & 0.07 \\
\hline Finland & 0.69 & & 4.00 & 0.14 & India & 0.76 & & 1.81 & 0.07 \\
\hline Greece & 0.62 & & 3.89 & 0.07 & Korea & 0.76 & & $6.24 *$ & 0.11 \\
\hline Iceland & 0.28 & & $11.39^{*}$ & 0.02 & Phillipines & 0.44 & & 4.32 & 0.12 \\
\hline Ireland & 0.78 & & 3.68 & 0.03 & Ghana & 0.53 & & 0.24 & 0.11 \\
\hline Spain & 0.52 & & $10.80^{*}$ & 0.07 & Morocco & 0.82 & & 2.98 & 0.07 \\
\hline Turkey & 0.14 & & 2.49 & 0.36 & Nigeria & 0.35 & & 6.15 & 0.13 \\
\hline Australia & 0.30 & & 8.58 & $0.67 *$ & Sudan & 0.39 & & 1.12 & 0.26 \\
\hline Bolivia & 0.17 & & 4.86 & 0.29 & Tunisia & 0.66 & & 4.33 & 0.16 \\
\hline Brazil & 0.79 & & 7.82 & 0.08 & Hong Kong 1/ & 0.64 & & 6.15 & 0.07 \\
\hline Chile & 0.61 & & 7.65 & 0.09 & Malaysia 1/ & 0.73 & & 1.60 & 0.09 \\
\hline Colombia & 0.53 & & 5.44 & 0.10 & South Africa 2/ & 0.56 & & 6.49 & 0.03 \\
\hline Costa Rica & 0.78 & & 1.69 & 0.18 & Argentina 2/ & 0.67 & & 4.09 & 0.26 \\
\hline Dominican Republic & 0.39 & & 1.38 & 0.08 & Mexico 2/ & 0.60 & & 4.71 & 0.03 \\
\hline Ecuador & 0.26 & & 1.90 & 0.03 & Uruguay 2/ & 0.60 & & 1.57 & 0.10 \\
\hline El Salvador & 0.16 & & 8.56 & 0.04 & Taiwan, P.O.C. 2/ & 0.59 & & 3.87 & 0.10 \\
\hline Guatemala & 0.11 & & 7.14 & $0.82 * *$ & Singapore $3 /$ & 0.80 & & 2.81 & 0.05 \\
\hline Haiti & 0.80 & & 2.30 & 0.12 & Kenya 3/ & 0.56 & & 0.60 & 0.08 \\
\hline Honduras & 0.64 & & 1.98 & 0.08 & Côte d'Ivoire 3/ & 0.78 & & 1.55 & 0.08 \\
\hline Nicaragua & 0.17 & & 7.70 & 0.33 & Algeria 4/ & 0.70 & & 1.13 & 0.08 \\
\hline
\end{tabular}


Table A2 (continued). Current Account Balances (in percent of GDP), 1960-2004

Autoregressive Coefficients (under revision)

\begin{tabular}{|c|c|c|c|c|c|c|c|c|c|}
\hline Country & AR1 5/ & $\mathrm{R}^{2}$ & LM[4] 6/ & Stability 7/ & Country & AR1 5/ & $\mathrm{R}^{2}$ & $\mathrm{LM}[4] 6 /$ & Stability $7 /$ \\
\hline Mauritius 4/ & 0.65 & & 2.35 & 0.20 & Bangladesh 12/ & 0.69 & & 5.85 & 0.26 \\
\hline Benin 5/ & 0.27 & & 1.46 & 0.08 & Mauritania 12/ & 0.64 & & 2.32 & 0.07 \\
\hline Togo 5/ & 0.27 & & 2.35 & 0.11 & Bahrain 13/ & 0.89 & & 6.20 & 0.23 \\
\hline Indonesia 6/ & 0.49 & & 0.95 & 0.09 & Kuwait 13/ & 0.22 & & 0.23 & 0.61 \\
\hline Thailand 6/ & 0.89 & & 4.39 & 0.09 & Oman 13/ & 0.04 & & 0.19 & 0.13 \\
\hline Uganda 6/ & 0.04 & & 7.66 & $0.94 * *$ & Botswana 13/ & 0.28 & & 6.37 & 0.10 \\
\hline France $7 /$ & 0.65 & & 2.26 & $0.88 * *$ & Lesotho 13/ & 0.70 & & 4.17 & 0.23 \\
\hline Netherlands 7/ & 0.62 & & 4.31 & $0.48^{*}$ & Nepal 14/ & 0.81 & & 0.89 & 0.89 \\
\hline New Zealand 7/ & 0.52 & & 2.54 & 0.18 & Poland 14/ & 0.63 & & 1.66 & 0.34 \\
\hline Saudi Arabia 7/ & 0.72 & & 1.62 & 0.03 & Albania 15/ & 0.16 & & 6.76 & 0.08 \\
\hline Pakistan 7/ & 0.65 & & 0.60 & 0.10 & Bulgaria 15/ & -0.06 & & 5.82 & 0.03 \\
\hline Syrian Arab Rep. 8/ & 0.13 & & $9.73 *$ & 0.20 & & & & & \\
\hline Gabon 8/ & 0.43 & & 0.88 & 0.18 & & & & & \\
\hline Niger $8 /$ & 0.68 & & 3.98 & 0.07 & Average & 0.35 & & $\ldots$ & $\ldots$ \\
\hline Senegal 8/ & 0.66 & & 4.50 & 0.09 & Pooled OLS & 0.47 & & $\ldots$ & $\ldots$ \\
\hline Gambia 9/ & 0.52 & & 8.39 & 0.03 & Panel Fixed Effects & 0.50 & & $\ldots$ & $\ldots$ \\
\hline Madagascar 9/ & 0.17 & & 7.32 & 0.08 & & & & & \\
\hline Hungary $9 /$ & 0.55 & & 2.85 & 0.09 & & & & & \\
\hline Congo, Republic of $10 /$ & 0.05 & & 2.82 & 0.11 & & & & & \\
\hline Romania $10 /$ & 0.20 & & 1.91 & 0.06 & & & & & \\
\hline Portugal 11/ & 0.62 & & 3.60 & 0.05 & & & & & \\
\hline Papua New Guinea 11/ & 0.75 & & 2.70 & 0.18 & & & & & \\
\hline \multicolumn{10}{|c|}{$\begin{array}{l}\text { 1/ Estimation period 1965-2004. 2/ Estimation period 1970-2004. 3/ Estimation period 1975-2004. 4/ Estimation period 1980-2004. } \\
\text { 5/ Coefficient on first-order autoregressive term. 6/ Test statistic from Lagrange Multiplier test against } 4^{\text {th }} \text {-order serial correlation in the residuals. } \\
\text { 7/ Denotes Hansen test for stability of the AR1 coefficient }\end{array}$} \\
\hline
\end{tabular}

